\title{
Secularism in Exile
}

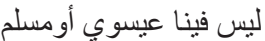

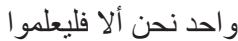

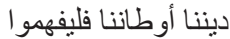 \\ إنَّا عرب تحاثنينا الفتن \\ آه...فلتحبا فلسطين لنا

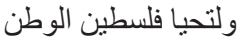

There are among us neither Christian nor Muslim.

We are one! Let them know

Our religion is our homelands! Let them understand

We are Arabs! We shun sedition!

O! Long live Palestine for us!

Long live Palestine, the homeland!

Seventy-two years old and recovering from surgery, Khairy Abudayyeh ("Abu Hatem," 1940-2019) leaned forward across his dining room table, face animated, voice deep and gravelly, to denounce "the religious fever" in Chicago and in the Middle East, especially in "what's going on in Syria." A poster of Naji al-'Ali's "Handala" figure-which depicted the Palestinian refugee-hung from the wall behind him. ${ }^{1}$ Instead of uniting to resist Western imperialism and Israeli colonialism, he said, the "religious fanatics" had divided the Arabs, offering illusions of divine salvation. But secularists, too, were to blame. Their passivity had abetted the division and mimicked the religious mindset: "We just cannot ignore things," he said. "The solution does not come from God, it comes from us!" Abudayyeh sat up straight in his chair and gestured dramatically with his hand as he recited Iskandar al-Khouri al-Beit Jali's poetic declaration of Arab unity in the epigraph above. The performance hearkened to the Arab nationalist past and its principle that one's religion was the nation, that the nation was Arab, and that Arabs shunned sectarian division leading to "sedition."

Abudayyeh had memorized Khouri's poem as a schoolboy in the West Bank village of al-Jib some sixty years earlier. His teachers, swept up in the pan-Arabism 
of the 1950s, backed the Movement of Arab Nationalists (harakat al-qawmiyin alarab). Reeling from the war of 1948, they hearkened to its call to unite against Zionism and the West. Their students, including Abudayyeh, joined them in mass protests against the signing in 1955 of the Baghdad Pact, a Western-led military alliance that pan-Arabists viewed as propping up the monarchical regime in Iraq.

Six decades later, however, as Abudayyeh surveyed those early years, panArabism lay in disarray. The regimes that still espoused it had either fallen or were teetering in the face of the massive Arab Spring protests (December 2010-13, approximately) and the horrendously destructive wars that followed in their wake in Libya, Yemen, and Syria. Among Palestinians, too, the unity forged historically through the leadership of the Palestine Liberation Organization (PLO) had collapsed. An ascendant Hamas ruled Gaza; a sclerotic Fatah clung to the West Bank. And, it seemed, the malaise had spread: the mosques were on the rise in Chicago and secularism had weakened in the diaspora.

Abudayyeh was right about Palestine. He had a point-his provocative, polemical flourish notwithstanding-about Chicago, too. Organizations like the Mosque Foundation, Muslim Legal Fund of America, Council on American-Islamic Relations, and American Muslims for Palestine had become dominant within the immigrant community. These groups had also helped to form citywide bodies such as the Council of Islamic Organizations of Greater Chicago and national organizations like the Washington, DC-based lobby, the US Council of Muslim Organizations. The ascendancy of these groups mirrored a rise in Islamic religiosity among Palestinians and other Muslim-majority immigrant communities, as well. More women had begun wearing headscarves; more men had grown beards; more weddings featured gendersegregated celebrating; more stores advertised halal grocery items of various sorts (Cainkar 2004 and personal observations). The September 11 attacks and their long aftermath had cemented the shift by intensifying a media-driven perception of Islam as the primary identity of Muslims, generating a racist, anti-Muslim backlash, and thrusting religious leaders into the role of community representatives.

Yet, despite these developments, secularism persisted. It animated leaders of the Arab American Action Network (AAAN), the sole remaining secular social service and community organization on the Southwest Side. It informed the political orientations of activists involved with Students for Justice in Palestine chapters and with the Boycott, Divestment, and Sanctions (BDS) campaign on university campuses (Lybarger 2014). Other types of deinstitutionalized secularism had also emerged as part of a disenchanted response to the new piety.

The individuals who continued to express secularist or secular sensibilitiesamong those who participated in this project-lived with their families and neighbors in the suburbs, where they accommodated yet also felt alienated by the religiosity pervading their communities. ${ }^{2}$ Others resided elsewhere in the city, far from the suburban enclave. As the scope of secular nationalist institutional space receded, these individuals increasingly lacked a nucleus around which they could 
cohere as an identifiable presence. To embrace a secular orientation was, in the context of the religious turn, to inhabit a marginal, disconnected space, to live a disenchanted exile within the exile. ${ }^{3}$

\section{EXAMINING SECULARISM: WHY IT MATTERS}

If secularism in the Palestinian immigrant community has become marginal, why examine it? Three reasons present themselves. First, since the September 11 attacks and the subsequent wars in Afghanistan and Iraq, journalists and scholars have focused on Islam's compatibility with the West. ${ }^{4}$ This concern has led to an increasing emphasis on cultural-religious location in the analysis of Muslim politics and identity (Malik 2009). The contingency of Islam in the identities of Muslims has receded from view as a result. This obscuring of contingency prevents an appreciation of complexity. Muslims in Europe and the United States do not necessarily identify primarily in religious terms, and they hold often-contradictory viewpoints on the salience and meaning of Islamic religious norms (BBC News 2007; Pew Research Center 2007, 2011; Nagel and Staeheli 2011). By emphasizing persisting forms of secularism, I seek to acknowledge such contingency and, in doing so, to caution against the Islamizing of Muslims in scholarly and public discourse. I do not deny the fact of Islam's ascendancy as an identity frame within immigrant Muslim communities. Indeed, this book analyzes this process in detail as it has manifested in Palestinian Chicago. My point, simply, is that in their focus on Islam's growing cultural and political prominence, scholars and journalists often lose sight of how secularism and secularity shape the identities of individuals who happen to have Muslim backgrounds.

My second justification for focusing on secularism is methodological: understanding religious revitalization requires attention to secularism and secularity because the two phenomena exist in a dynamic, mutually constituting relation (Riesebrodt 2010; Casanova 2011). We see this dynamic manifesting among Palestinians. Combating secularism and secularization in Gaza's refugee camps, for example, was the primary objective of Hamas's precursor, the Islamic Collective, during the 198 os, and a main concern of organizations like the Mosque Foundation and various churches in the Palestinian immigrant community has been to inoculate families against "corrupt" secular influences in US society and culture. ${ }^{5}$ Any discussion of religious revival among Palestinians, then, requires, on theoretical and empirical grounds, a discussion of secularism as a competing, interacting formation.

Finally, and in connection with the previous point, the vicissitudes of Palestinian secularism demonstrate how social orientations reconstitute intergenerationally. Secular structures, even when they are weak, continue to instill secular orientations in new cohorts of activists. And the pious milieu itself can produce disenchantment and a search for secular (if not secularist) alternatives (see chapter 6). Palestinian secularism, and how it has developed over time and 
space, is then a highly complex phenomenon that bears directly the imprint of the religious turn.

\section{PALESTINIAN SECULARISM}

The secularism concept has had wide currency among Palestinians (Lybarger 2014). Khairy Abudayyeh offers a starting point for delineating a specifically Palestinian ideal-type. I do not claim that Abudayyeh is representative of Palestinian secularism as a whole. On the contrary, as a pan-Arabist (qawmi), his orientation constituted a very particular and contested trajectory of specifically political secularism. Still, the perspective he articulated conveys certain common features of secularism as Palestinians across the political spectrum have deployed it in Palestine and in the diaspora.

One of these shared features, the importance of national unity, appears in the poem Abudayyeh recited at his dining room table. The poem insists that Arab fraternity trumps religious solidarity: the nation-Arab and Palestinian-comes first. To promote Muslim or Christian solidarities at the expense of the nation is a treasonous act. One has to understand that one's religion, in the sense of a corporate loyalty, is the homeland. Such a perspective does not entail atheism per se but rather a reinterpretation of the purpose and meaning of religious practice. As Abudayyeh later explained, rituals like the pilgrimage to Mecca or fasting or prayer were salutary exercises that enabled, among other things, sharing experiences and solving problems, strengthening the body, and developing empathy for the poor. Such virtues were conducive to national unity. Palestinian secularism, as it emerges ideal-typically from Abudayyeh's self-presentation, then, annexes religions as contributing traditions that functionally nurture national cohesion: Palestinian Christians and Muslims are Arabs in the end, but what it means to see oneself as Arab includes, among other things, an ecumenical integration of subnational religious cultures (Islamic and Christian).

Palestinian secularism has proven to be historically resilient. This resiliency lies in the events, structures, and processes that reproduce it. Abudayyeh's secularism, for instance, stemmed, on his account, from the memory of his father participating alongside veterans of the Great Arab Revolt (1916-18) to fight the British during the 1936-39 Arab Revolt in Palestine. Abudayyeh described attempting later, as a child, to emulate his father's example by helping to distribute food to Palestinian fighters during the war of 1948. The pan-Arabism he later absorbed from his teachers during the 1950 s provided an ideological framework for the nationalism he had learned through his family and through the experience of war. In Chicago, he would convey these values to Palestinian youth through community institutions he helped to create. Secularism thus reconstitutes itself intergenerationally through its formational experiences, organizational structures, and discourses. The success of this process has depended on the ability of its institutions and 
narratives to render secularism meaningful to new cohorts of activists in each successive crisis.

\section{CONSTITUTING SECULARISM IN CHICAGO: THE GENERATION OF 1948-1967}

The founders of the secular nationalist organizations that predominated within the Chicago immigrant community prior to the 199 os came of age, politically, during the period of 1948-67. I fuse these two dates into a single generational event because it was during this nineteen-year span that the secular nationalist factions took form and coalesced into a coherent Palestinian national movement. This process imbued young adults who were forming their historical and political outlooks during this time with a shared sense of fate. Variations in orientation due to differences in temporal and spatial relation to the two wars certainly existed, but the common experience of these wars and of secular nationalism as the dominant framework of political solidarity and action in this period is the key point. ${ }^{6}$

\section{Social Backgrounds}

Arriving in the United States during the 1950s through the 1960s and early 1970s, members of the cohort of 1948-67 who participated in this project came from varied social backgrounds. Some were from families of the professional, landowning, and commercial strata in the towns and cities of Palestine. These individuals attended elite schools prior to their arrival in the United States. Musa (pseudonym) (1930-2018), a long-time leader in the Palestinian community, provided insight into the experience of this echelon during a 2011 interview for this project. Musa grew up in an elite Muslim family in a mixed Christian, Druze, and Muslim town near Haifa and Nazareth. His family owned land and many of its members had entered professional fields (medicine, teaching, engineering). He scored well on a British Mandate placement exam and was admitted into an exclusive school to prepare for civil service employment.? After the war of 1948, Musa immigrated to the United States, arriving in the mid-1950s to begin medical school. He eventually became a surgeon at a large city hospital, serving there until his retirement in 1990. His wife, who was from an elite Christian family with a secular orientation, became the head administrator of a large nonprofit organization. Their children would eventually study for advanced degrees, work in professional fields, and move to the northern suburbs.

Other individuals in the generation of 1948-67 who gave interviews for this project came from less privileged backgrounds. Typically, they grew up in villages and attended public schools in nearby towns. Khairy Abudayyeh attended a government school in his village and then, in 1960, when he was twenty years old, immigrated to the United States to join his father and brother in Chicago. Originally intending to go to college, he instead began helping his brother with his 
business. He later took courses sporadically at Roosevelt University in the Loop while holding various jobs, often more than one simultaneously. He eventually spent the majority of his working life as a purchasing agent for the Guarantee Trust Life Insurance Company. Abudayyeh's children would go to college and enter professional fields. His son, Hatem, for example, earned a bachelor's degree at the University of California-Los Angeles and then returned to Chicago to work as an athletics coach in a local public school before becoming the executive director of the AAAN in 2002.

Ali Hussain, born in the early 1950s, followed a similar trajectory. After attending grammar school in his village, he enrolled in a government high school in nearby Ramallah, a predominantly Christian town north of Jerusalem. In 1971, at the age of eighteen, Hussain travelled to the United States for college. "I knew no one and barely had a hundred bucks on me," he recalled. He rented a room in a student dormitory for twenty-five dollars a month and began studies at the YMCA Community College. Progress was slow. He had to take various jobs, including in a downtown hotel, to pay for his rent and meals. Eventually, he launched a financial services business on West $63^{\text {rd }}$ Street in the heart of the former Palestinian enclave in Chicago Lawn. He currently lives in a southwestern suburb and commutes to his West $63^{\text {rd }}$ Street office.

\section{Generational Processes in the Formation of the Cohort of 1948-1967}

Musa, Abudayyeh, and Hussain differed in their socioeconomic backgrounds, yet, they shared a similar secularist outlook and commitment. The signal events that shaped their common orientation were the two wars of 1948 and 1967 through which Israel established itself and then conquered the remainder of British Mandate Palestine. Direct experience of the violence instilled a sense of national solidarity and a commitment to resistance. Musa briefly joined one of the Palestinian guerrilla groups operating in the Galilee region. Abudayyeh, as noted, also experienced the fighting in 1948. Hussain witnessed the war of 1967 and the violent imposition of Israeli military occupation. He recounted an Israeli raid on his village to search for weapons in the aftermath of the war. Soldiers detained several men, including Hussain and his uncle. At the jail, soldiers beat his uncle in front of him until he admitted to having a Mandate-era rifle in his home. This experience and others like it politicized Hussain as a teenager.

The reinvigoration of the Palestinian national movement had an equally influential impact on the cohort of 1948-67. The main event in this revival was Fatah's takeover of the PLO in 1968. Fatah, active since the 1950s, had consistently prioritized independent Palestinian decisionmaking even as it negotiated Arab regime sponsorship and access to sites from which to launch cross-border guerrilla raids against Israel. The other major Palestinian resistance movement, the Movement of Arab Nationalists (MAN), had taken a different strategic and ideological approach. It predicated Palestinian liberation on Arab nationalist revolutions that would 
first overthrow monarchical regimes aligned with the West and then act in concert against Israel. The MAN aligned closely with Egyptian President Jamal Abd al-Nasser, who had become the preeminent tribune of secular pan-Arabism and a leader of the global Non-Aligned Movement.

The stunning defeat of Egypt, Syria, and Jordan in the war of 1967 dealt a severe blow to Nasser and the pan-Arabist cause, however, weakening the MAN as a consequence. In response, George Habash reconstituted the MAN as the Popular Front for the Liberation of Palestine (PFLP). The PFLP subsequently joined the PLO, becoming an important opposition force to Fatah within this framework. The forging of a unified national resistance prioritizing the armed struggle (al-kifah al-musallah) had an electrifying impact on young Palestinians. Even as the Middle East reeled in shock from the 1967 defeat, Palestinian and other Arab youth rallied to "the revolution," especially joining the guerrilla groups that had established bases in Jordan.

As in the Middle East, the war of 1967 generated a surge of nationalism within the Chicago community. Musa, Abudayyeh, and Hussain each cited this intensification of feeling as their motivation to become community organizers. Abudayyeh spoke of 1967 and its aftermath not as a defeat of Arab nationalism but rather as a moment of rejuvenation, in Chicago, of a commitment to Arab solidarity. He described a "birth of nationalism, a strong national movement" and cited the groups that formed from the Movement of Arab Nationalists as the inspiration. Musa, as well, noted that " 67 sparked people's awareness," whereas before the war "there was little political activism in the community."

Specific responses to the surge of nationalism varied in the community. Musa, for example, became a leader in organizations that leaned ideologically toward Fatah, the main PLO faction. He also helped found the Chicago chapter of the American-Arab Anti-Discrimination Committee. Through these involvements he became an important mediator across political and sectarian lines in the immigrant community. At one point, Musa assisted a predominantly Palestinian Christian group to conduct a needs assessment, collect money, and obtain a plot of land for a community center associated with their church. "Back then we didn't ask about religion [ . . . ]. We saw ourselves as Palestinians. As far as I am concerned Christianity is part of my heritage as a Palestinian Muslim." ${ }^{8}$

Hussain responded to the post-1967 nationalist sentiment by joining the Arab Student Association (ASA), which had emerged to counteract pro-Israel groups (Pennock 2017). The ASA held annual conventions that drew participants from "all Palestinian political factions and also from Iraq, Kuwait, Libya, Yemen." But, beginning in 1978, the organization fractured when Palestinian students split to form the Palestinian Students Association. Hussain commented: “That was one of the biggest mistakes the leadership made at that time [ . . . ]. We started excluding the activists in the community who were defending the Palestinian cause and we reduced it to only the Palestinian students." The Palestinian organization lacked 
funding and soon folded. Despite the fractures, the networks that grew from these groups mobilized young leaders within an emerging secular nationalist milieu in the city. Significantly, religious movements such as the Muslim Brotherhood did not present viable alternatives because they did not address the core national question that so urgently confronted the cohort of 1948-67. Hussain stated: "I'm proud to be Muslim, but the Islamists in the early ' 70 s here in Chicago were not active toward the cause [ ... ]; they would rather have somebody from Africa convert to be Muslim than unite as Arabs to liberate Palestine."

The post-1967 nationalist response also gave rise to new community-level organizations. For example, Abudayyeh and Hussain, along with a third individual, Samir Odeh, who had arrived in Chicago at the same time as Hussain and had studied with him at the YMCA Community College, helped found the Arab Community Center (the ACC, the markaz) in 1972. The center's activities included instruction in the Arabic language, in Arab and Palestinian history and politics, and in practices like tatriz (traditional embroidery) and dabka (village line dancing) that had become symbols of Palestinian identity. These activities replicated the way the PLO factions and their associated organizations in the Occupied Territories and in the refugee camps in Jordan and Lebanon raised national awareness. They generated a sense of national cohesion within the Chicago immigrant community, thereby marking a distinctive Palestinian and Arab presence in the city's Southwest Side.

\section{Institutionalizing Secularism}

The ACC would become a main social and political anchor of the Palestinian enclave in the Chicago Lawn area during the 1970 and 1980 os. Two other centers, also situated on West $63^{\text {rd }}$ Street, came into existence at approximately the same time. Their leaders and base constituencies were known to align ideologically with Fatah and with one of Fatah's opposition groups in the PLO, respectively. By contrast, the Arab Community Center was understood to orient toward pan-Arabism, Third World internationalism, and the political left within the PLO. ${ }^{10}$ All three centers sought to mobilize Chicago Palestinians in relation to the national liberation effort. They did so through cultural programing, financial support for families and communities locally and in Palestine, and protest actions. The ACC and its successor organization, the Arab American Action Network (AAAN), with which I have had the strongest connection and familiarity, reflects this organizing work in a broad sense."

The ACC's initial location was on the North Side near the intersection of North Belmont and West $42^{\text {nd }}$ Street. A small Palestinian community had formed in this area, and some of the organizers, including Khairy Abudayyeh and Ali Hussain, were living there at the time. The majority of Palestinians, however, had settled on the city's Southwest Side. This fact led the center's leaders to relocate the ACC to premises near South Rockwell and West $55^{\text {th }}$ Street in the Gage Park 
area. "The rent was $\$ 650$ and we were wondering where the hell we were going to come up with the money; it was a huge place," Hussain remembered. Searching for an affordable alternative, they relocated again in 1978, this time permanently, to a building in the Chicago Lawn area on West $63^{\text {rd }}$ Street near South Kedzie Avenue. The ACC continued until 1995. A year later, a new organization, the AAAN, took its place in the same premises under a new generation of leaders. These leaders had grown up attending ACC events as well as participating in the Union of Palestinian Women Associations (UPWA) programs, which also had been situated at the ACC.

The ACC's social outreach focused on youth. Parents dropped off their children after school. Abudayyeh and Hussain and their fellow activists, who went directly from their jobs to the center, taught the language, history, and culture classes. Hussain brought his own children and typically "ten to fifteen of their neighborhood friends" with him in his van. "I was teaching Arabic classes there from 1972 all the way to 1995," he recalled. This focus on youth became a guiding concern of the center's programs. Samir Odeh (1951-94), one of the founders and also a director of the ACC, for example, launched the Youth Delinquency Program, the first initiative of its kind to address the needs of Palestinian and Arab teenagers on the Southwest Side (Abowd 1995). The ACC initiatives became a model for other community centers nationally. In 1979, Odeh participated in the creation of the National Network for Palestinian Community Empowerment, an organization that trained local community organizers. He traveled across the United States, visiting Arab community centers and helping their staff recruit membership and build programs (Abowd 1995).

The ACC also became a social and political hub during major crises such as the Israeli campaign against the PLO in Lebanon in 1982 and the First Intifada (1987-93). ACC organizers facilitated communication with loved ones "back home" and coordinated letter-writing campaigns, marches, blood banks, clothing drives, and an extensive sponsorship program for families in Palestine. These efforts sometimes drew the scrutiny of law enforcement. During the 1982 Lebanon war, for example, Chicago police arrested Ali Hussain on drug-smuggling charges after suspicious neighbors reported seeing discarded medical equipment_-syringes-in the dumpster behind the center. The association had collected the implements but deemed them inadequate for sending to Lebanon. Hussain's colleagues immediately fanned out across the Southwest Side to collect funds for his bail. A National Lawyers Guild attorney-an individual of Irish ethnic descent who supported the Republican cause in Northern Ireland-volunteered to defend Hussain. ${ }^{12}$

The willingness of this lawyer to volunteer his time revealed an additional dimension of the work that Hussain and his colleagues had undertaken in their effort to organize Palestinians in the city: building ties to other immigrant and minority groups and their community centers. These ties solidified during Harold Washington's campaign to become the first African American mayor of 
Chicago in 1983. The ACC's leaders contributed financially and volunteered their labor to that campaign, their first ever venture into city politics. After the election, the new mayor held his first Southwest Side "town hall" meeting at the ACC (Abowd 1995). Hussain and other ACC leaders like Odeh remained involved in efforts to build coalitions and run Arab candidates for local office. Odeh, for example, chaired the outreach committee for Illinois Voters for Middle East Peace from 1985-90. The committee focused on Arab voter registration and sought avenues for Arab participation in city government. These efforts led Washington to institute the Advisory Committee on Arab American Affairs. Odeh and the ACC also joined Reverend Jesse Jackson's Rainbow Coalition in 1988, strengthening bonds with African American civil rights leadership nationally (Abowd 1995).

Hussain, Odeh, and other ACC activists had learned that mobilizing political pressure and developing political access were crucial to defending the Palestinian community and its interests. They worked within established entities like the Democratic Party but also forged alliances with other minority and immigrant community organizations in order to build Palestinian and Arab political capacity. Referring to his arrest in 1982, Hussain reflected on the importance of those ties and on their later weakening:

The community and our allies came together, and that support helped to place pressure on elected leaders to dismiss the charges. Leaders of other [ethnic] communities, including business people, testified that our center were good people who actually worked against drug crime in the area. Our situation today is different [... ]. We don't come together like this anymore."

\section{Deinstitutionalization and Attenuation}

In 1991, a fire gutted the building in which the Fatah-oriented Palestinian Community Center was situated. ${ }^{13}$ The center's leadership never rebuilt the institution. The second center associated with one of Fatah's competing factions also closed at this time. A year later, the ACC sealed its doors. The shuttering of these centers signaled the deinstitutionalization and corresponding social and political weakening of secularism - a process that paralleled the crippling of the PLO during and after the first Gulf War (1990-91) and also the powerful rise of Islamist competitors, principally Hamas, in the Occupied Territories (primarily, the Gaza Strip). Even though the AAAN would soon replace the ACC-largely due to a successful effort to transform the markaz into a grant-funded social service organization-the institutional shift favoring Islamic religious organizations in the southwest suburbs had become decisive. Individuals committed to Palestinian liberation would participate in these new Islamic institutions, but the religious framework would not have the same intersectarian Arab and Palestinian nationalist focus as the community centers in the former Chicago Lawn enclave. The creation of American Muslims for Palestine (AMP) in 2006 would address this lack of a 
political advocacy structure (see chapter 3). Significantly, however, the AMP, as its name suggests, oriented itself explicitly in religious sectarian terms.

The events leading to these changes were complex. They included the demographic transition and corresponding religious institutionalization in communities like Bridgeview beginning in the latter half of the 1980s (see chapter 1). Ali Hussain, Musa, and Khairy Abudayyeh acknowledged these processes but pointed to two other factors: the decision not to move the secular community centers to the suburbs and the inability of the Oslo Peace Process (1993-present) to produce an independent Palestinian state. Working in tandem, these two factors, they argued, undermined the capacity of secular nationalists to respond effectively to the growing influence of the Islamic organizations. Hussain observed:

After 1995 [two years into the Oslo Peace Process], people were really in despair about politics and our community centers weren't there [for them in the suburbs]. This opened the door to the Islamist people taking over the community. It became the trend to follow the shaykh wherever he goes, do whatever he says; whether it's the right thing or wrong thing, people followed them. We lost our entire base, practically.

The Islamic shift also gained momentum from the perception, in Hussain's recounting, that "the [Fatah-led] nationalist movement was not doing good over there [in Palestine], there was no liberation, no state." The disenchantment with secularism, he said, led to the embrace of religion as an alternative. The change was dramatic: "You used to walk in this neighborhood [Chicago Lawn] back in the ' 8 os and you would hardly find women with hijab [ ... ]. But now, suddenly, in Bridgeview, you hardly see anyone without it."

Khairy Abudayyeh echoed Hussain's assessment. "Oslo discouraged everybody [among the secular nationalists]," he said. "It put a damper on our activities." In addition to the demoralizing psychological impact, there was the problem of legitimacy stemming from a perception that the PLO had betrayed the cause of liberation and statehood: "The religious fanatics started saying to us, 'Your cause is useless! See what nationalism did to you! See what Communism did to you! See what Arafat did to you!' We didn't have an answer."

The difficult position reflected in Abudayyeh's comments reflected how the Oslo Peace Process had transformed the terms of the conflict by bringing the PLO, which had become politically isolated and financially undermined during the first Gulf War, into alignment with Israel and the United States. Diaspora activists confronted a situation in which the objectives of solidarity and advocacy were no longer clear. The agreement appeared to fall short of what had been the PLO-led consensus goal, independent statehood within the post-1948 ceasefire lines and the return of the refugees. With Oslo, the PLO seemed to have capitulated to a limited form of autonomy within highly circumscribed territorial zones (the patchwork of areas, delimited as A, B, and C, with differing levels of Israeli security control). This dispiriting result left diaspora activists despondent and adrift. As Abudayyeh 
noted, Islam-oriented leaders saw an opportunity to declare the failure of secular nationalism and propagate the message that only with a return to Islam would Palestinians, and Muslims globally, recover the homeland. As late as 2014, in fact, this exact idea was the main message of a speech that a Mosque Foundation imam gave at the annual American Muslims for Palestine Nakba Day commemoration (see chapter 3). ${ }^{14}$ Palestine would return to Palestinians one day, the imam said, but the key to this eventuality lay in the return of Arabs and Muslims to Islam.

In addition to the changed political context, Abudayyeh pointed to other factors contributing to the weakening of secularist organizations. "We also were busy with our families and jobs," he said, "six or seven of us, the founders and some other people, we had jobs and families and less time to give the community and that gave an opening to the religious fanatics, too." The reliance on volunteer labor indicated a relative lack of professionalization at organizations like the Arab Community Center. By contrast, from the 1980 os through the 200os, the Mosque Foundation significantly enlarged its complex, alongside the two new Islamic schools, providing a full range of religious and social programing as it did so. The Islamic institutions, in this way, became an all-encompassing canopy for community life and individual leisure time in the expanding suburban enclave (Lybarger 2014).

Nostalgia marked the outlook of the secularists of the 1948-67 cohort as they reflected on what had occurred since the 1990s. During his 2012 interview for this project, Khairy Abudayyeh recalled a gathering of the old guard at the home of a family whose daughter had just graduated from college that summer. The party featured Palestinian food and a musician who played nationalist songs. "The women were not wearing hijab scarves," he remembered, "it was like the old days when we would get together, women and men, Muslims and Christians, without boundaries."

Musa also commented on the difference between past and present: "The leftists," he said, "had a devout Muslim as president of their community center [the ACC] for many years!" He added:

That was an example of how people separated the two. You could be religious in
your personal life but in public you were a Palestinian [ . . . . What's going on now
is Saudi-influenced [ ... . People start meetings of supposedly secular organizations
with "al-salamu 'alaykum" ["Peace be upon you"-a typical Islamic greeting and also
a phrase that ends the mandated ritual prayers] and they pause their activities for
prayer [ ... . It didn't used to be like this; this is Saudi stuff.

The extent to which Saudi influence had propelled the religious turn in the suburbs was unclear. What was relevant in Musa's comment, however, was how it reflected his estrangement from the Islamized present. Marked by piety, even in ostensibly secular settings, this present had become foreign to what was, in his view, genuinely Palestinian. For secularists of the generation of 1948-67, to see oneself as Palestinian was to embrace an ethic of national solidarity that acknowledged religious differences but insisted that such distinctions should remain bounded 
within individual life. In public, one was Palestinian. To assert otherwise, whether through rhetoric or sartorial practice, was to divide the nation.

Yet, as Musa's remarks indicated, a younger cohort of secular activists-which formed in the period of 1987-2001-appeared to be at ease with an overt hybrid construction of public space as simultaneously religious and secular. These activists seamlessly incorporated Islamic invocations at the start of supposedly secular events. This shift appeared to signal a new conception of the normative boundaries of the religious and the secular in public life. Interviews with leaders in this new cohort, however, nevertheless revealed an underlying ambivalence about the change.

\section{THE GENERATION OF 1987-2001}

Since the 1990s, leadership of secularist institutions within the Palestinian immigrant community in Chicago has passed to a new cohort of activists. I demarcate this generation in relation to the period of 1987-2001. This period encompassed several key events: the First Intifada, a mass uprising against the Israeli occupation in the West Bank and Gaza Strip; the Gulf War, in which the United States led a military campaign to force the Iraqi army out of Kuwait in 1990-91; the Oslo Peace Process, which began in 1993 but then ground to a halt with the outbreak of the Second Intifada (the al-Aqsa Intifada); and, finally, the September 11, 2001 attacks in the United States. These events, carried into living rooms via cable and satellite television, mobilized a new generation of secular nationalist activists.

During this same period, the Islamic shift began to reshape Palestinian social and political identities in Palestine and in diaspora communities like Chicago. The resulting secular-Islamist split defined the generation of 1987-2001 in both places. In Chicago, the Islamic shift corresponded with an enfeeblement of secular nationalist structures. The new generation of secularist leaders had to adjust to this transformation. A flexible accommodation of the public assertion of religion and of the predominance of Islamic institutions in the suburbs distinguished their outlook from the attitudes of secularists of the 1948-1967 cohort, who, like Musa, insisted that religiosity be restricted to personal life or, like Abudayyeh, saw religious sectarianism as a threat to national unity. The three profiles that follow illustrate how the generation of 1987-2001 accommodated the new religiosity but also expressed deep misgivings about it.

\section{Manal}

Manal (pseudonym), a former volunteer at the ACC on the Southwest Side of the city, was a family physician in private practice when I interviewed her in her large home in a southwestern suburb. Born in Jerusalem in the mid-196os, she had spent much of her childhood in Austin, Texas, where her father completed an engineering degree at the University of Texas. She returned to Palestine in the 1980 s to attend high school in the Jerusalem area. This high school, which featured 
an English-language curriculum and American teachers, catered to wealthy, US-born Palestinian children.

Manal described becoming conscious of her American identity while at the school. Local residents referred to her and her classmates as "amrikan." The political factions, she told me, generally avoided recruiting students at her school because "[we] were not really seen as 100 percent Palestinian [ . . ]. You were somehow tainted by America because you grew up there, and you were frowned upon by those who were less educated." Manal commented further that the perception stemmed from observed differences in social comportment: "We had no problem walking out into the street in t-shirts and jeans, going and coming freely-most girls back home [in Palestine] don't do that-and speaking with the opposite sex, with American [Palestinian-American] boys at the school; we saw that as normal." Manal's comments about the suspicion she encountered indicated how Palestinians in Palestine-or, at least, those individuals who lived near her school-could perceive the diaspora as a morally corrupting force, especially for girls.

Despite the local skepticism, Manal nevertheless became politically active. She participated in after-school demonstrations, school council, and a dabka dance troupe that toured the West Bank. The artistic activity was especially important to her. Her family had urged her to avoid public protests and political organizing, but the dance troupe "was acceptable, it was art-political action in artistic form that would not necessarily subject you to danger [ . . . ]. We were allowed to do that."

Manal did eventually become involved in organized activism, but that development only occurred after her return to the United States, to Chicago, to begin college in the late 1980 s. Manal's description of this phase reflected, in particular, the importance of the organizations that activists of the generation of 1948-67 had established during the post-1967 period. It also reflected how Chicago's wider metropolitan area afforded her freedom from community social controls. Living on her own in a rented apartment near the university, Manal had the ability to engage in political activity in ways that had not existed for her in Palestine due to the close scrutiny of female public behavior. ${ }^{15}$

Manal's integration into the specifically secular nationalist political milieu in Chicago occurred through the General Union of Palestinian Students (GUPS) chapter at her campus. She joined GUPS after meeting some of its members at an event. She then became president of the chapter during her senior year. Through GUPS she established connections with the ACC. Leaders at the center invited her to join in their programs and activities. As a single woman living on her own, she especially appreciated the "chance to meet people [ . . . ]. There was a Palestinian women's organization [the Union of Palestinian Women Associations] and I was a member of that, was very active there, and a dabka group that would meet every Friday night to practice, and they held Thanksgiving complete with turkey and hummus for those who didn't have families [ . . . . All the other major holidays were celebrated there." 
Through such activities, the ACC eased the transition for newly arrived immigrants and for students living on their own. It provided a home and the support of friends. Equally important, however, was the opportunity to engage in various types of activism on behalf of the Palestinian cause. In her comments, Manal described a time of heightened political advocacy in the period after her graduation from college in 1985. In December 1987, the First Intifada began. The ACC's premises quickly became a site of round-the-clock activity. Community members came frequently to the center to learn about events and take part in food and medicine drives.

The Union of Palestinian Women Associations (UPWA), which was headquartered at the ACC, played a key role in facilitating the logistics of these efforts. It integrated women into the work of the campaigns and empowered them politically in the process. Manal described, for example, how English classes attracted women initially and then how teachers would recruit their students into UPWA and ACC work. This process led to the formation of a core of activists who staged conferences and conventions. At these events, Manal and her fellow organizers would perform dabka, lead singing of nationalist songs, plan activities, and educate the community, women especially, about current events and the need for gender equity. The UPWA also held an annual banquet that attracted more than a thousand participants. "At that time," Manal commented, "people felt they had a national identity and wanted to have these gatherings and were willing to contribute money [ ... ]. Now, no one wants to talk about contributing [to nationalist organizations], but, people back then were giving thousands and thousands of dollars to the [refugee] camps and to Palestine."

After medical school, during the 1990s and 200os, Manal continued to engage in Palestinian activism. She described this period as a moment of secularist collapse that left the immigrant community without an organizational structure through which to advocate for Palestine. I reminded her of American Muslims for Palestine (AMP), which was founded in 2006 in the wake of Israel's "Summer Rains" bombardment of the Gaza Strip in retaliation for Hamas's abduction of Israel Defense Force Corporal Gilad Shalit. Hadn't this organization filled the gap created by the collapse of the community centers? I asked. Manal claimed not to know much about AMP but pointed out that it had an explicitly Islamic identity: by definition it ruled out the inclusion of Palestinian secularists, atheists, and Christians. She noted that locale-oriented organizations like the Ramallah club did integrate non-Muslims into the Palestinian community, but these structures were "more social than political." In moments like Israel's repeated attacks on Gaza, there was no mechanism, no secular mechanism, to bring all Palestinians together. "That's the flaw in the political organizing of the Palestinians in this community [ . . ] ], she commented. "The will and desire are there, and you can tap into it and into the resources, and you can massage the anger that builds up, but what's the mechanism through which all of this is going to flow?" The absence 
of such a mechanism led Manal to conclude there was no "organized community" other than at the Mosque Foundation and its associated groups, but these religious associations excluded important segments of Palestinian Chicago.

Faced with the lack of a secular organizational alternative, Manal found that she could not avoid participating in the new pietistic milieu and its structures. She described, for example, sending her children to the Islamic schools next to the Mosque Foundation to learn Arabic and Islamic heritage. "I'm not a religious person," she said, "however I wanted them to have a little bit of religion in them and I wanted them to know the language [ . . . ]. People have different reasons for sending [their kids] — not just because we want to indoctrinate them into religion, but for limited purposes, like language and culture." She monitored her children's experience and eventually removed them: "[I took them out] when it reached the point, where, in my view, what they were learning had nothing to do with Palestinian values, and they were being brainwashed, in my opinion." She placed her children in the public schools, instead.

In these comments, Manal revealed how the Islamic religious turn had begun to affect secularist practices and sensibilities. Her perspective toward religion was continuous with the attitudes of the generation of 1948-67, which viewed Islam as an historical inheritance or individual practice but resisted it as a frame for shared political identity. The difference in the generation of 1987-2001, of which Manal was part, lay in its pragmatic participation in religious institutions. In the aftermath of the religious shift, this generation of secularists had few other options for retaining ties to Palestinian immigrant life and identity in Chicago.

Reflecting on this predicament, Manal commented on the need and the prospect for reviving a nonsectarian, secular space in the community. The lack of such a space became particularly apparent when children began to search for marriage partners. The capacity of the secularist milieu to regenerate itself resided partly in its ability to institute and transmit its value orientations intergenerationally within families. Meeting marriage partners was critical to perpetuating these family structures. She commented:

We all got married through the markaz, we all met our spouses there. Now, when your child is older and he's dating and he says, "Mom, introduce me to someone," where am I gonna send this kid? Where? Where??! There really is no community. We don't go to church or mosque. The mosque isn't an environment for this kind of social interaction.

The absence of secular spaces also had eroded intergenerational collaboration, a factor in the weakening of secular structures. "One thing our organizations are not doing," Manal said, "is reaching out to the older people for guidance [ . . . ]. You still need the old group that has access to wider circles, families that can organize, that have access to people and to money [ . . . ]. The younger people do not have this access." As Manal described: "We used to raise maybe twenty, thirty, forty 
thousand dollars at our annual banquet, and we thought it was a million bucks back then, but, today, the shaykhs at the Mosque Foundation can raise a million dollars in less than a half-hour on a Ramadan night."

Having lost their place in community life, the secular nationalist organizations faced difficulty sustaining their fiscal viability. The break in intergenerational ties had compounded this problem. The occasional moments when secular spaces did reemerge brought their relative absence into stark relief. When I described Khairy Abudayyeh's account of a party someone had given to celebrate a daughter's university graduation, Manal said she remembered the event, too:

You know what it was? It was the markaz on a Friday night twenty-five years ago! Arabic music, singing, Arabic food, old and young, women and men, freely socializing. We were there as Palestinians: Christians and Muslims and secularists. No one wearing hijab, no one going off to pray. We need to revive this type of thing, because that will turn into political organizing on a much higher level. I don't have the anger Abu Hatem [Abudayyeh] has. You really can't blame anybody. It was a natural state of affairs given our leadership overseas and the current situation [the failed Oslo process].

The nostalgic tone in Manal's recollection of the graduation party emphasized the fact that the secular ethos no longer existed as it once did. The heart of organized community life lay elsewhere, in the mosque programs and Islamic schools and in social gatherings structured according to reformist, pietistic norms such as weddings featuring gender-segregated celebrating. There was no intersectarian, secular alternative for gathering and leisure other than the occasional dinner party. Like Ali Hussain, Manal blamed the dispiriting impact of the Oslo agreement and failed peace process. Still, she said, "we could revive our gatherings and organizations with some extra commitment."

Whether or not the secular milieu could actually revive itself in the manner that Manal suggested remained uncertain. Younger Palestinian activists had a range of options for continuing their involvement in the cause after they finished college. Many joined in AMP activities, for example (see chapter 3). As Hatem Abudayyeh, son of Khairy Abudayyeh and Executive Director of the AAAN, told me, "We are in a bit of a competition with AMP over these kids-we don't know which way they'll go."

The religious shift had also drawn in secularists themselves. Manal mentioned several former leftists who had become pious and "converted." She interpreted this phenomenon as a reaction to the failures of secularism and the corresponding need for meaning and direction in life:

Many of the old guard at the markaz that had been very involved in organizing the community went into depression mode [after Oslo]. They asked themselves, what place do I have in this process now? Everything we've been struggling for has suddenly vanished. Where do we go from here? And many of them to this day have not 
found the answer. They have disappeared off the political spectrum. Some have even gone in the Islamic direction. These people [who embraced the Islamic turn] felt abandoned. The mosque was there to say: 'See where your secularism got you! It got you nothing but failure and corruption. But, we have the answer! Join us now!' You were no longer feeling Palestinian; it no longer did anything for you. Islam now was what mattered, what seemed to give hope, the way forward. You were Muslim now. A lot of people converted. People who used to call themselves socialists were now wearing hijab and praying five times a day.

Manal, by contrast, had found a third path between withdrawal and conversion. Secularism persisted within her outlook in this intermediate trajectory. She combined guarded participation in the Islamic institutions-limited attendance at Saturday morning religion classes for her children, for example-with the nurture of informal gatherings in which the former secularist ethos could again revive, albeit momentarily. She also occasionally volunteered for the AAAN. Secularism had dissipated but not disappeared, and this was the case even in the suburbs where Manal and other secularists had moved along with their piety-minded neighbors.

\section{Mahmoud}

The next profile of an individual of the generation of 1987-2001 illustrates a different developmental track from the demoralization-to-conversion and the accommodation-and-persistence trajectories that Manal witnessed and experienced. This alternative movement extended to a space of secularity beyond the Palestinian immigrant milieu. Within this space, Palestinian identity broadened into a multisectarian, cross-national Arab American solidarity that transcended the dilemma, for secularists, of the religious shift.

My interview with Mahmoud (pseudonym), a chemical engineer in his late thirties at the time of our conversation, provides insight into this other possible trajectory. We began our discussion in his downtown office and then continued for several hours at his favorite restaurant in the Loop. Born in the Arab Gulf region in 1975, Mahmoud arrived two years later in the United States. His father, a trained accountant in the United Arab Emirates, joined his brothers in a restaurant business on the Northwest Side. Five years later, the family moved to the immigrant enclave in Chicago Lawn, where Mahmoud's father started a new restaurant. The restaurant failed, at which point the father recertified as an accountant and began work in the City of Chicago's taxation department.

Mahmoud had limited contact with Palestinian community organizations on the Southwest Side. His lack of connection stemmed partly from the fact that his family had moved into the area during his final year of high school. He had not grown up in the community. Still, he described sporadically attending the Saturday Arabic classes at one of the secular nationalist community centers (not the markaz). These classes, he recalled, lacked discipline and a coherent curriculum. He attended a few initial sessions but then stopped. Mahmoud also described 
going to community fundraisers at the center to support charitable causes in Palestine. The family was still on the North Side at the time. Attending those events required a thirty- to forty-minute car ride across the city. "I think this was around the time of the Israeli invasion of Lebanon in 1982," he told me, "but I was too young to appreciate what was going on."

After graduating from high school in 1993, Mahmoud followed his father's example by pursuing a two-year degree at a South Side city college. Attending this college had the unforeseen consequence of integrating Mahmoud into a Palestinian student milieu and into organizing structures such as GUPS. He initially participated in GUPS, but the factional infighting alienated him. He recalled one event in particular: an election for the governing board at the college:

You had all the [PLO] factions in GUPS [ ... ]. I remember making the argument that we were a small group on the South Side at this small community college so who gives a shit about this [factional loyalty] stuff. We were sitting around in the cafeteria smoking and arguing but we weren't accomplishing anything. We had the elections and we shut down the entire cafeteria. And all the other students were like, what the hell! Everyone else has a small ballot box but the Palestinians have to shut down the entire cafeteria because they are fighting over the results. I remember when I walked in to vote, some guy who was not from the college, he was from UIC (University of Illinois at Chicago) - there was this hierarchy with the UIC GUPS chapter controlling our chapter [ ...], it was like organized crime the way the territory was divided up-this guy takes my ballot before I even walk into the room and he scribbles something on it in Arabic. I said, 'What the hell is that!' He said, 'Don't worry about it.' I said, 'Fuck you! Don't worry about it?! You can't write on my ballot!' I said, 'Fine, I'm turning in a blank ballot!' My cousin, who was at UIC, said later, 'So, Mahmoud, you turned in a blank ballot!' [laughter]. I said, 'How the hell did you know?!?' I really did not like the whole faction nonsense. One faction would win, take over the office, and never do anything. Absolutely useless. At that point, I figured I could do a lot more to benefit the community as a whole, Palestinian and non-Palestinian, Arab, Muslim and Christian.

Mahmoud's recollection highlights the extent to which, in the early 1990s, secular nationalism and its ideological factions remained the dominant structure of politics and identity on the college and university campuses that drew immigrant Palestinian enrollments in the city. This period coincided with the beginnings of the Oslo Peace Process, an event that momentarily rehabilitated the international status and authority of Yasser Arafat and the Fatah movement. Oslo, however, also deepened the factional divides among secular nationalists. The leftist Popular Front and Democratic Front groups, for example, rejected Fatah's decision to enter into the Oslo process. Mahmoud encountered this deepening divide-and a corresponding demand for party loyalty-on campus.

After two years at the community college, Mahmoud transferred to the University of Illinois at Chicago (UIC), where he earned bachelors and masters degrees 
in chemical engineering. During this period, he joined the American-Arab AntiDiscrimination Committee (ADC), a civil rights organization that advocated for Arab Americans as a distinct, cross-national ethnic group in the United States. Mahmoud's interest in the ADC developed after seeing its spokesperson, James Zoghby, defend Arabs and Muslims on national television following the Oklahoma City bombing in April $1995 .{ }^{16}$ Inspired by Zoghby's public advocacy, he contacted $\mathrm{ADC}$ to see how he might contribute. Within a year he was serving on the board of the organization's Chicago chapter. At Zoghby's invitation, he also took part in an ADC factfinding trip to Palestine. The objective was to support the Oslo process and to hear directly from the Palestinian Authority leadership about how Arab Americans, especially, could advance Palestinian interests in the United States. This trip, which introduced Mahmoud to Palestinian politics at the highest level, solidified his sense of Palestinian identity. But it also situated this identity and his activism on behalf of it within an Arab American framework.

Soon after returning from the ADC trip, Mahmoud founded an association for Arab professionals and assisted in the creation of an Arab American advocacy group within the city's Democratic Party. These activities brought Mahmoud to the attention of Mayor of Chicago, Richard M. Daley. Immediately following the September 11 attacks, Daley invited Mahmoud to join the Arab Advisory Board. This entity, established under the previous Harold Washington administration, provided a channel of communication and patronage to the city's Arab American community. Similar advisory boards existed for other ethnic blocs in the city, as well. ${ }^{17}$ Within a year, Mahmoud accepted a three-year appointment as an advisor to the Daley Administration.

The embrace of an Arab American identity, as well as mainstream political assimilation through that identity (for example, within the Chicago Democratic Party), allowed Mahmoud to resist and transcend the pressures of political factionalism in the Palestinian immigrant community. Those pressures became irrelevant and disappeared for him within the broader Arab American space. Similarly, the Arab American context allowed him to negotiate the Islamic religious shift by providing him with an alternative reference group that reinforced an ethos of pluralism.

The religious shift directly affected Mahmoud. His mother and aunts began to wear the hijab scarf, for example, and his parents started to fast and pray regularly during the early 199os. Mahmoud linked the changes to the process of religious institutionalization in the suburbs. "It had to do with the conservative movement in Chicago," he said. "Maybe it's the shaykh at the Bridgeview Mosque who started it; he and his supporters insisted that [... ] women had to wear hijab, everybody had to pray, everybody had to come to the mosque, and a lot of people kind of went in that direction." Mahmoud had resisted this trend. "I haven't fasted or prayed for twenty years," he told me. His refusal to conform sometimes caused tension and awkwardness. He described how feelings of estrangement arose during large family gatherings: 
Sometimes I feel like an outlier. For example, over the weekend we had two iftars [the meal that occurs after sunset and that breaks the daylong fast during Ramadan] with one hosted by my uncle, the other by my cousin. And there were some very conservative, very religious family members in both groups. And there were also a lot of non-observant family members-some, I should say some, not a lot.

The awkwardness Mahmoud experienced at these Ramadan dinners disappeared, by contrast, when he convened with his friends in the professional organization he had established. In this space, a middle ground existed, made possible by a tacit agreement to allow and respect diverse lifestyles:

If I'm out with a lot of the younger Arab Americans-like this group I started for Arab American professionals-a lot of them are non-observant. We have drinks when we go out. We don't pray five times a day. Some of us might fast, but like me not everyone does. A lot of us have the same opinion: respect for the religion, just not observant. Some of us have a problem with religion because of the leadership, seeing them use religion for political gain, distorting the religion for their own interests [ ... ].

As he reflected on the ethos of this group of peers, Mahmoud recounted how his father had instilled a basic "live and let live" orientation within him as a child. He recalled two incidents, in particular, in which his father conveyed the importance of accepting difference and of placing moral rectitude above religious observance:

[Once] when I was 11 [ . . ], after we had someone who was religious over for dinner, my father said, 'Listen, religion is good, and it's good if you observe religion, but that's not the only thing you should strive for. You can be a good person without religion, and there are people who are religious who are bad people. So, you need to be a good person first and foremost, and then accept religion or not. It's your decision.' Religion was never forced on us, never shoved down our throats. Another time, my sister and I, when she was in seventh grade and I was in sixth, were telling our dad [about] this guy in school named Ethan and he's Jewish. My dad asked us what he was like. My sister and I, being goofy and silly, both said, 'He's ugly'. We thought it was hilarious, we said it at the same time. But then we got lectured by my father, let me tell you! He said, 'That's unacceptable, you can't do that, you don't judge somebody by their religion, there are a lot of good Jewish people. Our problem is not with Jewish people; it's with the Israeli government-the policies. Never judge anybody based on their background.'

Out of place within the Islamizing spaces of the family and wider immigrant community, Mahmoud attempted to mirror his father's values of acceptance but did so from the contrasting stance of someone who "didn't care for religion," personally. Like his father he sought to respect the choices of others. In doing so, he articulated a type of soft secularism that bridged the religious and the secular, or at least allowed them to coexist within the community that his professional peers constituted. His father, especially after his turn toward a heightened piety during the 1990s, likely would not have spoken of his values as "secular." Mahmoud, however, 
had clearly adapted them to a secular sensibility that above all else privileged individual autonomy in matters of belief and practice, religious and political.

As with Manal, Mahmoud accommodated the religious shift: it was a fact he accepted. But, unlike Manal, he defied its institutional gravity by joining and creating alternative Arab American spaces that transcended the nationalist and religious particularisms of the Palestinian immigrant milieu. This transcendence did not necessarily mean disengagement from Palestine advocacy. The Arab American context, as his work with the ADC demonstrated, retained a central concern for Palestine. What Mahmoud transcended was the specifically Palestinian political and communal space. He was not nostalgic, as Manal and Khairy Abudayyeh were, for the secular nationalist ethos that once prevailed. Its factionalism had alienated him from the start.

\section{Hatem Abudayyeh}

My final profile of the generation of 1987-2001 features Hatem Abudayyeh, Executive Director of the AAAN and son of Khairy Abudayyeh. ${ }^{18}$ Abudayyeh has dedicated his entire working life to Palestinian community empowerment and Palestinian advocacy within the secular nationalist structures that his father helped to create. His path thus contrasts sharply with Mahmoud's transcendence of the Palestinian political space and with Manal's and even his father's sense of living in the aftermath of secularism's marginalization.

In our conversations, Abudayyeh vigorously denied that the Islamic religious shift had made secularism irrelevant. The religious shift did not signal a fundamental change. The conditions of Palestinian life, in his view, remained inexorably secular. The central matter of Palestinian liberation was still unresolved. Moreover, the social and political challenges that the immigrant community faced in Chicago required approaches and resources the mosques simply could not provide. Secular organizations devoted to political advocacy and community support were therefore indispensable.

Abudayyeh has been the AAAN executive director since 2002. During this time, he has overseen significant expansion of AAAN's social programs. The organization provides translation and transportation services as well as referrals for legal, housing, counseling, childcare, and domestic violence assistance. It has developed a range of youth and women's programs. It also provides English as a Second Language classes. In addition to service provision, the AAAN has engaged in public advocacy to counter anti-Arab racism and discriminatory policies. In doing so, it has forged strategic alliances with other immigrant communities and immigrant rights organizations. These alliances have proved crucial to supporting the public positions that AAAN has taken, for example, against US government actions such as the Trump Administration's "Muslim Travel Ban" in 2017.19 Individual AAAN personnel, including Abudayyeh, have also helped lead protests against Israel's actions in the West Bank and Gaza Strip as well as against 
US Department of Justice investigations targeting community leaders since the September 11 attacks. These activities have occurred through separate coalitions, not necessarily as AAAN initiatives. ${ }^{20}$

Abudayyeh described his individual activism and his work at the AAAN as stemming from the tradition of Arab nationalism that inspired his father's generation. He spoke with great pride of this political inheritance: "Syrian Ba'athists, Iraqi Ba'athists, the Arab National Movement, the Nasserites, all of those different trends of Arab nationalism in general, that's the political background my parents came from. And, that, by osmosis, is the political background that I learned."

The osmosis metaphor was apt. It connoted immersion and absorption within a larger political culture that preserved, reinforced, and instilled the traditions of secularism intergenerationally. Abudayyeh described this culture, which pervaded the ACC, the AAAN's organizational predecessor, as integrating Arabs of diverse backgrounds who shared a commitment "not only to Arab nationalism but to internationalism." This international focus led the markaz founders to "support [ ... ] other national liberation struggles-it's why our organization today has great relations with the Puerto Ricans in Humboldt Park, with the Mexican nationalists and Chicano nationalists in Pilsen and Little Village, with the African American communities [... ]. It's because of the political perspective these people brought from the Arab world." Americans, he said, did not understand this fact. They viewed Arab nationalism through the lens of the Iraq War and the corresponding media discourse that portrayed the late Saddam Hussein and Ba'athism as totalitarian and repressive. They did not know "about the different Arab nationalist parties, how some of them built the first leftist organizations and instituted very progressive policies in their countries." Abudayyeh expressed pride in this history: "I grew up in a progressive home and community. The issues of women's rights and class contradictions were at the forefront of everything I understood about my struggle and the struggle of other peoples."

Ironically, Abudayyeh's transformation into a community organizer and ultimately the AAAN director would not begin in the Palestine activist community in Chicago but at the University of California-Los Angeles (UCLA), where he completed his bachelor's degree. The first Gulf War (1990-91) erupted during this time. Anti-war protest gripped the UCLA campus. Abudayyeh became involved with the students organizing these protests. The organizers forced him to confront inconsistencies between his professed beliefs and actual behavior. "I had the tendency to talk a lot [at rallies]," he said, "because I read the stuff [radical political theory], I understood the stuff, but I wasn't really an activist or an organizer." He recalled one female student, in particular, who challenged him: "She told me: 'Confronting these rich students and their privilege is absolutely correct, but, you know, you don't do any work, you're not an organizer, not an activist, you're not involved in any activism work!' [ . . . . For her, it was all rhetoric and it didn't 
mean shit!" Challenged in this way to enact his principles, Abudayyeh decided to abandon his medical school plans and instead return to Chicago to "make a difference in the community."

The establishment of the AAAN in that same moment provided Abudayyeh with an opportunity to shift into community organizing. After a brief stint coaching athletics in a local high school, he applied for a position as a coordinator of the youth program at the new organization. "I called Dima [pseudonym] out of the blue," Abudayyeh recounted, "and asked if there was anything available." Dima, a close family friend, had worked with Abudayyeh's mother to lead the Union of Palestinian Women Associations. She encouraged Abudayyeh to apply for the coordinator position. The organization soon offered him the job.

In taking a staff position at the AAAN, Abudayyeh completed his transition to the vocation and identity of an activist. In doing so, he continued the commitments his parents embodied, embracing a politics of Palestinian liberation and Arab community empowerment. He did so, however, at the exact time the secularist milieu had begun to collapse despite the AAAN's debut. Like other markaz/ AAAN activists, he pointed to Oslo's failures, as well as to the collapse of the Soviet Union and the transition to a unipolar world dominated by a single United States superpower allied with Israel, as reasons for the loss of secular influence. He also stressed the failures of secularists to offer viable and attractive alternatives in the suburbs. This failure, however, did not mean that there was no longer a place for secular community organizations. "Ninety percent of our social services clients come from the southwest suburbs," he observed, "so those issues of economic sustainability for families and the community are still there even though those folks seem to be upwardly mobile." Moreover, some Palestinians continued to live in the Southwest Side neighborhoods. "I would say if you look at the economic levels," he commented, "it's not a whole lot different. A large percentage [is] still under the poverty line in the suburbs just like in Chicago Lawn." The claim, then, that the base had become wealthy and did not need the services that the AAAN offered was only partly accurate.

Abudayyeh admitted, nevertheless, that "we have to move to the suburbs; when it comes down to it, we have to." The organization's identity as an "urban organization" committed to "progressive change" in alliance with other oppressed minority communities, especially "the black and Latino communities," however, made it difficult for its members to imagine a move. "It's the core of our identity," he said, "something we have worked hard at, these alliances, ever since my father's time, and it's been really hard for some of us to understand that moving to the suburbs, where our base is located, is the correct path."

But, if the AAAN did move, it would recover its relevance, Abudayyeh asserted. The premises would be "jam-packed, alive from 8:00 a.m. till 10:00 p.m. like the markaz used to be in the '7os and '8os." This would happen because few other groups offered programming focused on the community's most pressing needs: 
I think people in the southwest suburbs, families, want the type of youth programming that we provide. We offer a safe social and political space for young men and young women to come together in programming, respectful programming, respecting class differences, respecting gender differences, understanding systems of oppression, discussing and challenging systems of oppression. I don't think that every single family in Bridgeview wants to send their children to the mosque for their youth development. Many would prefer the programming we offer here. We discuss Palestine and the Arab world but also the taboo issues: violence in the home, double standards, and patriarchy, all of those things. I don't think anybody's talking about patriarchy in the Islamic institutions in the southwest suburbs. The Mosque Foundation and other Islamic centers seem like they're the main institutions because there are no attractive secular organizations nearby. If I want my kid to learn Arabic, he's going to have to go to an Islamic school. There is no Arabic language instruction in Chicago's public schools or in the suburban public schools, even those with huge Arab populations. ${ }^{21}$ I know some parents who say, 'Listen, I want my kid to learn Arabic but not just in the context of Qur'an memorization.' That stuff might not be part of my political or even my cultural background, you know, this, faith-based political Islamic stuff; but where else am I supposed to go?

The appearance of an Islamic turn within the community was therefore deceptive, according to Abudayyeh. The community's needs were still secular in character. Those needs stemmed from, among other things, the persisting challenges of poverty, domestic abuse, and political repression of Arabs and Muslims, generally. The "Islamic turn," for Abudayyeh, reflected an absence of secular organizations capable of answering to non- "faith-based" needs rather than a substantial change in the value orientations of the community. ${ }^{22}$ Secularism remained relevant even if secularist structures had weakened or were missing in the spaces in which Palestinians now lived.

Still, for many young AAAN program participants and staff, Islam was a manifest identity orientation. These individuals wore headscarves or beards and prayed in the corners of the AAAN's premises. During Ramadan, as I noticed on one occasion, their computers were set to the times that sounded the adhan-the call to prayer-for the breaking of the fast. Whatever else it might have meant, seeing oneself as Palestinian now intertwined with the embrace of an Islamic piety that typified the religiously transformed ethos of the suburban enclave.

Abudayyeh implicitly acknowledged this fact. He accommodated the piety of the younger activists in the AAAN workspace, whereas twenty-five years earlier markaz leaders had resisted public expressions of religiosity. ${ }^{23} \mathrm{He}$ also partnered with the mosques and with groups like American Muslims for Palestine to solicit support for AAAN programs and for social justice campaigns and protest actions: he simply could not ignore the Islamic religious leadership, which could mobilize thousands of constituents, as coalition partners. At the same time, Abudayyeh insisted correctly on the inescapable priority of the secular. The Islamic turn had 
not cancelled or overcome the fundamental struggle for Palestinian liberation and community empowerment. In Abudayyeh's view, secularism's continuing relevance and the possibility of its renewal remained latent within this ineluctable reality.

\section{A SECULAR AFTERWORD}

On May 15, 2014, the Students for Justice in Palestine (SJP) chapter at the University of Chicago commemorated the Nakba ("the Catastrophe"), the Palestinian Arabic term for the forced displacement of nearly three-quarters of a million Palestinians in 1948. The SJP remembrance featured photographs and brief speeches and a buffet of hummus, falafel, and shawarma. The main event was an impassioned performance by Remi Kanazi, a young Palestinian spoken word artist from Brooklyn.

Of Christian background, Kanazi, in his poetry, excoriates sectarianism. The poem "Religious Harmony," for example, which Kanazi performed, begins with an indignant oath in which the speaker declares, "If I hear one more person ask my religion, [thinking it] would shape and define my worldview," then "I'm gonna flood his people, kill his firstborn [ . . ]" (Kanazi 2011, 27). The poem proceeds to scorn Zionist claims that Muslims persecuted Jews and Christians in Palestine before 1948. Zionist militias, the poem says, killed and dispossessed Palestinian Muslims and Christians alike. The next stanzas deride Republicans and "liberal secularists" alike for stoking fears about Islam while ignoring poverty and racism in the United States. ${ }^{24}$ It ends with the narrator declaring that even though he was raised a Christian he cannot see why that should matter in a world in which one also hears, while walking in Brooklyn to the subway, the call to prayer on Fridays. The speaker in the poem proclaims to never have known "religion by name" in such a world but instead holds above all else to a "faith in my people" (Kanazi 2011, 28). Throughout Kanazi's performance, the audience, including the SJP chapter president, a young woman who grew up in Chicago's suburban Palestinian enclave, attended the Islamic schools next to the Mosque Foundation, and wore a hijab scarf, snapped their fingers in appreciation. As he concluded, they applauded enthusiastically.

Kanazi's performance at the SJP event underscores the core assertion of this chapter: that despite its weakening, secularism nonetheless persists. The weakening is certainly evident. With the notable exception of the AAAN, the institutional structures of the secular nationalist milieu in Chicago have atrophied or disappeared entirely since the 1990s. This phenomenon has occurred alongside the withering of the PLO and the imploding of the diaspora as an organized political force generally (Frisch 2012). At the same time, however, secularism has not entirely disappeared. As Manal and Hatem Abudayyeh show, the institutions and traditions that the cohort of 1948-67 established reproduced secularist orientations within the generation of 1987-2001. Manal's narrative demonstrated this 
fact: organizations like the General Union of Palestinian Students as well as the Arab Community Center and Union of Palestinian Women Associations integrated her into the secularist milieu, and in the process reinforced a secularist orientation within her. Abudayyeh's narrative revealed additional elements of this process: crises like the first Gulf War and the political formations that mobilized a wider US antiwar response proved critical as catalysts for the reappropriation and reproduction of the progressive and secular Arab nationalism that he had absorbed in his family. A wider US institutional context was also crucial for trajectories leading to a secular transcendence beyond the immigrant enclave and its sectarian tensions, religious and political. Mahmoud, who had assimilated through participation in the American-Arab Anti-Discrimination Committee into a wider Arab American activist and US political culture, exemplified this process.

Secularism persisted, as well, as the "background," or condition of possibility, of the religious shift itself. The next two chapters-which show how the religious milieu has constructed itself in tension with secularism-demonstrate this fact. At the same time, the religious turn has generated new hybrid forms of "syncretic secularity." These forms are reactions to Islamization, in particular (see chapters 5 and 6). In each of these respects - in the continuity of its traditions and structures, in the role it plays as the foil of the religious turn, and in the ironic production of new forms of secularity through the disenchantment that the religious shift provokes-secularism has retained its relevancy and force. 